\title{
Nietzsche: Metaphysician
}

ABSTRACT: Perhaps the most fundamental disagreement concerning Nietzsche's view of metaphysics is that some commentators believe Nietzsche has a positive, systematic metaphysical project, and others deny this. Those who deny it hold that Nietzsche believes metaphysics has a special problem, that is, a distinctively problematic feature that distinguishes metaphysics from other areas of philosophy. In this paper, I investigate important features of Nietzsche's metametaphysics in order to argue that Nietzsche does not, in fact, think metaphysics has a special problem. The result is that, against a long-standing view held in the literature, we should be reading Nietzsche as a metaphysician.

KEYWORDS: history of philosophy, Nietzsche, metaphysics, metametaphysics, methodology

Interpreters have long disagreed about how to approach Nietzsche's view of metaphysics. Perhaps the most fundamental disagreement is that some commentators believe Nietzsche has a positive, systematic metaphysical project, and others deny this. By 'positive' I mean that Nietzsche endorses some metaphysical claims, and by 'systematic' I mean that Nietzsche more or less regularly endorses such claims. Those who interpret Nietzsche to have such a project include, among others, Kaufmann (I974), Heidegger (I987), Schacht (1983), Richardson (1996), Hales and Welshon (2000), Remhof (2018), and Doyle (2018). Let this be called the metaphysical reading.

The opposition is what I call the non-metaphysical reading. Those who support such a reading absolutely deny that Nietzsche has a systematic metaphysical project, and they often deny that he makes any positive metaphysical claims at all. Berry $(2005,201 \mathrm{I})$, for instance, argues that Nietzsche recommends suspension of belief toward all metaphysical and epistemological claims. Ansell-Pearson contends that Nietzsche's philosophical program, at least in his middle period, is a 'practical-therapeutic . . . attempt to overcome metaphysics' (Ansell-Pearson 2018: 4). And Poellner believes that in most of the later writings Nietzsche embraces 'metaphysical indifferentism', the antimetaphysical view that most metaphysical disputes are pointless (Poellner 2013: 696, see also 2009: I70-77). One might arrive at the non-metaphysical reading by other routes as well. For example, one might argue, as we often see in postmodern interpretations from Derrida (I978) onward, that Nietzsche denies that metaphysical language can refer to the way the world is (see, e.g., Houlgate I986: 38-95, esp. 77ff). Indeed, when reviewing the

My thanks to Scott Jenkins, Andrew Kissel, Teresa Kouri Kissel, Joseph Swensen, Matthew Meyer, Brian Leiter, Daniel Z. Korman, and two anonymous reviewers at the Journal of the American Philosophical Association for helpful comments on earlier drafts of this paper and ideas developed in this paper. 
secondary literature one often reads about how Nietzsche aims to 'free philosophy entirely from metaphysics' (Emden 20I4: I33) or 'recommends that we dismiss all types of metaphysics' (Himmelmann 20I9: 210) or suggests an 'opposition to metaphysics in general' (Stern 20I9: 36I). At the very least, it looks like 'Nietzsche is much better understood not as a great German metaphysician', or even 'as very interested in metaphysics' (Pippin 20I0: 9). There should be no doubt that the non-metaphysical reading is dominant in the literature.

My aim is to offer a compelling challenge to this reading in order to show that Nietzsche is a metaphysician. I proceed by examining important features of metametaphysics in Nietzsche's writings, that is, his view of the nature and methodology of metaphysics. It is well-known that Nietzsche professes to attack 'metaphysical philosophy' (HH I: I) and that he calls himself a 'godless anti-metaphysician' (GS 344). ${ }^{\mathrm{I}}$ But does this mean that he rejects metaphysics simpliciter? On my view: absolutely not. The upshot is that we should be approaching Nietzsche as a metaphysical philosopher. Delineating which kind of metaphysician he is or what metaphysical commitments he has is not my goal here -I have offered thoughts on such issues elsewhere. I set out to undermine the reading that for Nietzsche metaphysics in general is problematic. I offer no substantive defense of the metaphysical reading, then, but simply try to show that the non-metaphysical reading, which has long been present in the literature, has no legs to stand on. We should then part ways with this reading.

Here is how I come to this conclusion. Rather than spend time offering internal criticisms of each non-metaphysical reading, I challenge them all at once. I do so by examining whether Nietzsche thinks there is a special problem for metaphysical philosophy, such that metaphysics is somehow problematically discontinuous with other areas of philosophy. I am indebted to Bennett (20I6) for developing this strategy for investigating metaphysics in general. There are four ways that Nietzsche might think metaphysics has a special problem. It might be the case that $(\mathrm{I})$ the primary philosophical question investigated by metaphysics is problematic; (2) the answer that metaphysics commonly gives to a dominant philosophical question is problematic; (3) the philosophical methodology of metaphysical inquiry is problematic; or (4) the subject matter of metaphysical philosophy is problematic. If Nietzsche thinks that one or more of these constitute a special problem for metaphysics, then it would do substantial work to establish the non-metaphysical reading. And if not, then it clears the ground to support the metaphysical reading. My view is that Nietzsche does not think that metaphysics has a distinctive problem, and so we have good reason to believe that the metaphysical reading is the right approach.

\footnotetext{
${ }^{\text {I }}$ I cite Nietzsche's texts using the standard abbreviations of their English titles: A is Antichrist; BGE is Beyond Good and Evil; D is Daybreak; EH is Ecce Homo; GM is On the Genealogy of Morals; GS is The Gay Science; HH is Human, All Too Human; KSA is the Kritische Studienausgabe; PT is Philosophy in the Tragic Age of the Greeks; TI is Twilight of the Idols; TL is 'On Truth and Lies in a Non-Moral Sense'. I use the Kaufmann and Hollingdale translations of A, BGE, D, EH, GM, and HH. I use the Nauckoff translation of GS, the Cowan translation of PT, the Large translation of T, and the Breazeale translation of TL.
} 


\section{What is a Special Problem?}

What does it mean to say that there is a special problem with metaphysics? Let us start with what it means to say that a feature of a discipline is special or distinctive. I adopt Bennett's (20I 6: 23) helpful view here. According to Bennett, to say that some feature $F$ is distinctive to $d$ is to say that a notably greater portion of $d$ s (members or instances of $d$, etc.) than non- $d$ s have $F$, and a good proportion of $d$ s have $F$.

To illustrate, consider Popper's solution to the problem of what demarcates scientific theories ( $d s$ ) from nonscientific theories (non- $d s$ ). Popper holds that nonscientific theories have a special feature $(F)$ : the claims of nonscientific theories are not falsifiable. Scientific theories offer explanations and predictions that can potentially be rendered false. According to Popper, physics and chemistry are sciences, whereas Freudian psychoanalysis and Marxist interpretations of historical development are mere pseudosciences. The former, but not the latter, are distinctively falsifiable. Of course, Popper seems to think scientific theories are necessarily falsifiable, and if so, then such theories are certainly distinctively falsifiable. But a distinctive feature of some domain certainly need not be a necessary feature.

Bennett applies this characterization of a special (problematic) feature to metaphysics. She writes that 'there is a special problem with metaphysics just in case there is at least one problematic feature or activity that is reasonably widespread in the discipline, but nonexistent or at least notably less widespread outside the discipline' (Bennett 20I6: 24). If metaphysics has a feature not shared by other sorts of philosophical inquiry, such as ethics or aesthetics, and that feature is for some reason problematic, then metaphysics would have a distinctive problem. For instance, if it were to turn out that contemporary metaphysical philosophy distinctively avoids naturalistic constraints on inquiry, as Ladyman and Ross (2007) argue, and if avoiding such constraints means that 'standard analytic metaphysics contributes nothing to human knowledge' (Ladyman and Ross 2007: vi), then metaphysics would have a special problem-assuming, of course, that metaphysics aims to contribute something to human knowledge.

The non-metaphysical reading holds that according to Nietzsche metaphysics has a special problem. On this view, Nietzsche is interested in embracing philosophical positions that concern areas such as ethics, aesthetics, philosophy of religion, or moral psychology, but not metaphysics. The idea is that metaphysical philosophy is somehow discontinuous with other forms of philosophical inquiry. For the non-metaphysical reading, Nietzsche believes that the primary question metaphysics investigates, the primary answer metaphysics gives to the question it investigates, the methodology of metaphysics, or the subject matter of metaphysics is distinctively problematic. I look at each of these below.

Going forward, it is important to note that some commentators who support the non-metaphysical reading, such as Berry, also believe that Nietzsche does not endorse any positive, systematic epistemological position. This would not detract from the view that for Nietzsche metaphysics is distinctively problematic, because, plausibly, the features that might render metaphysics problematic can be distinguished from the features that might render epistemology problematic. 
However, if both metaphysics and epistemology are problematic, albeit in different ways, it would not help my cause much to show that for Nietzsche metaphysics is not distinctively problematic merely because it is continuous with epistemology. Thus, in what follows I focus on examining Nietzsche's view of metaphysics in relation to areas of philosophy outside epistemology.

\title{
2. Nietzsche on What Metaphysics Asks
}

Perhaps Nietzsche thinks that metaphysics is distinctively problematic because the primary question driving metaphysical inquiry is problematic. Evidence for this reading might be found in Human, All Too Human, which begins as follows:

\begin{abstract}
Almost all the problems of philosophy once again pose the same form of question as they did two thousand years ago: how can something originate in its opposite, for example rationality in irrationality, the sentient in the dead, logic in unlogic, disinterested contemplation in covetous desire, living for others in egoism, truth in error? Metaphysical philosophy has hitherto surmounted this difficulty by denying that the one originates in the other and assuming for the more highly valued thing a miraculous source in the very kernel and being of the 'thing in itself'. (HH I: I)
\end{abstract}

Nietzsche diagnoses one of the primary problems of philosophy as trying to explain how something can originate from its opposite, and he reports that metaphysics has a particular answer to this question: metaphysical philosophy denies that opposites develop from each other and instead holds that the higher valued opposite, such as truth over error, ultimately derives from a source outside the world of experience, like Kant's thing in itself, Plato's Forms, or Christianity's Kingdom of Heaven.

Let us momentarily bracket an examination of Nietzsche's opinion of this particular answer. I want to point out that answering the question of opposites implies first asking the question, and Nietzsche begins the passage by reporting that the question is a problem for philosophy in general: 'Almost all the problems of philosophy once again pose the same form of question as they did two thousand years ago'. The question concerning opposites metaphysicians are trying to answer is the same question philosophers are trying to answer. This entails that doing metaphysics is doing philosophy in general. In this sense, metaphysics and philosophy are continuous. There is no special problem with metaphysics here. The question driving metaphysical inquiry does not constitute a feature of metaphysics that is either nonexistent or notably less widespread outside metaphysical philosophy.

Of course, one might argue that we cannot rely on Human, All Too Human to come to such a conclusion because it is an early work. But the position reappears in Beyond Good and Evil. Nietzsche writes:

How could anything originate out of its opposite? For example, truth out of error, or the will to truth out of the will to deception? Or 
selfless deeds out of selfishness? Or the pure and sunlike gaze of the sage out of lust? Such origins are impossible; whoever dreams of them is a fool, indeed worse; the things of the highest value must have another, peculiar origin - they cannot be derived from this transitory, seductive, deceptive, paltry world, from this turmoil of delusion and lust. Rather from the lap of Being, the intransitory, the hidden god, the 'thing-in-itself' - there must be their basis, and nowhere else.

This way of judging constitutes the typical prejudgment and prejudice which give away the metaphysicians of all ages. . . . The fundamental faith of the metaphysicians is the faith in opposite values. (BGE 2)

The second paragraph reveals that the first paragraph concerns how Nietzsche sees the mind of the metaphysician. The metaphysician is providing an answer to a question that other philosophical disciplines, such as epistemology and ethics, also want answered. As a result, there is nothing distinctively problematic in asking about the origin of apparent opposites. To ask this question is simply to take part in doing philosophy.

One might respond by saying that Nietzsche thinks asking the question of opposites is a distinctive problem for philosophy in general as opposed to other disciplines, like the sciences. If so, and if what I have said so far is correct, then metaphysics is problematic by implication. If Nietzsche rejects the question of opposites as problematic, then my view that Nietzsche thinks philosophy and metaphysics are continuous does not help my case. Both disciplines would be seeking answers to a misconceived question, and thus both would be problematic.

Notice, however, that Nietzsche offers responses to the question concerning opposites in both $\mathrm{HH}$ and BGE. These responses not only assume that he thinks the question can be answered, but that the question deserves an answer. 'Historical philosophy', he says, 'has discovered . . . that there are no opposites' (HH I: I). And, 'For one may doubt, first, whether there are any opposites at all, and secondly whether these popular valuations and opposite values on which the metaphysicians put their seal, are not perhaps merely foreground estimates, only provisional perspectives' (BGE 2). To make these claims is to accept that one of the primary questions of philosophical inquiry can and should be addressed. The answers Nietzsche favors, of course, might be considered uncommon. In $\mathrm{HH}$, for instance, he appeals to what we can learn about opposites from the natural sciences. But the point is that Nietzsche offers philosophical responses to the question concerning opposites, which shows that he does not think the question is a distinctive problem for all philosophical inquiry.

\section{Nietzsche on How Metaphysics Answers}

Perhaps the specific answer that metaphysicians give to the question of opposites is special, though, such that metaphysics does face a problem distinct from other forms of philosophy. As we saw above, metaphysical philosophy, according to Nietzsche, is primarily characterized by separating the world of experience, or the 'apparent world', from a world outside of experience, or the 'true world'. This way of 
understanding metaphysics loosely brings together Plato (BGE I4; TI 'Ancients' 2; KSA I 2:7[2]), Christianity (BGE II, 54; TI 'Reason' 6), Kant (HH I: I6; BGE I6; TI 'Reason' 6; A IO), Schopenhauer (HH I: 26; KSA I2:IO[I 50$]$ ), and Anaxagoras and Parmenides (PT). Kantian things in themselves, the Forms, the Kingdom of Heaven, and so on, exist outside the scope of experience. These are 'true worlds', using Nietzsche's vocabulary, because they are said to constitute, ultimately ground, render possible, or even redeem the world of experience. Importantly, Nietzsche despises the divide between 'true' and 'apparent' worlds. For instance, he asserts that the 'true world' is one of the 'most malignant errors of all time'; it is a 'mendaciously fabricated world' (A ro, see also EH P: 2). He therefore proclaims that 'it is of cardinal importance that one should abolish the true world' (KSA I3:I4[103]).

To see whether metaphysics is specially problematic, then, we need to see whether Nietzsche thinks we can do metaphysics without answering philosophical problems by perniciously dividing worlds. And I think the answer is clearly 'yes'. Arguably, however, it might beg the question against the non-metaphysical reading simply to address this issue by describing some of what appear to be Nietzsche's preferred metaphysical commitments. So, instead, I first want to establish independent criteria of what constrains an adequate characterization of metaphysics. It will emerge that the criteria do not require dividing worlds. We then need to examine whether Nietzsche's preferred responses to the question concerning opposites satisfy the criteria. If so, we would have good reason to think that Nietzsche believes metaphysical inquiry is not distinctively problematic on account of the age-old answer it gives to a common philosophical problem.

\section{On What Metaphysics Is}

I would like to offer three criteria of what constitutes an adequate characterization of metaphysical philosophy. Providing a full defense of these criteria would of course take us too far afield. To this end, I will simply cite outside sources for further discussion and move quickly through each. I want to emphasize that these criteria do not merely capture what we consider to be metaphysics in contemporary philosophy. The criteria should indicate, in broad terms, that thinkers before Nietzsche, such as Descartes, Kant, and Schopenhauer, in addition to current thinkers, like Hasslanger, Sider, and van Inwagen, all do metaphysical philosophy. There should then be reason to suppose that, if Nietzsche's philosophy indeed satisfies the criteria, he is doing metaphysics.

The first criterion of an adequate characterization of metaphysics is that metaphysics must be distinguished from science (see Bennett 2016: 29; van Inwagen 2007: sect. 4). There must be some notable difference, otherwise separating the two would be a distinction that comes to nothing. This criterion is especially important given that Nietzsche appears to be sympathetic to philosophical naturalism, the view that philosophy must be somehow continuous with the sciences. The exact nature of this continuity relation is disputed in the literature, but in order to say that Nietzsche is a metaphysician it must turn out that the relation is compatible with some feature that differentiates metaphysics and science. 
The second criterion is that metaphysics must investigate and draw conclusions about the nature of reality. This might involve investigating the basic categories of reality (see Aristotle 20I6: Book IV; Loux and Crisp 20I7: I-I6), reality behind what appears as reality (see van Inwagen I998: II; Sider 2008: I; Crisp 2016), the fundamental nature of reality (see Sider 20I I: I, Schaffer 2009: 379; Manley 2009: I), or the most general features of reality (see Kim and Sosa I999: ix; Le Poidevine 2009: $\mathrm{xx}$ ). This list is obviously not exhaustive. This criterion is necessary for understanding Nietzsche given that certain versions of the non-metaphysical reading deny that Nietzsche is committed to any claims concerning the way the world is. If it turns out, for example, that Nietzsche is merely doing conceptual analysis, or that he takes no stand on whether metaphysical language refers to reality, then he is not doing metaphysics.

The third criterion, which qualifies the second, is that metaphysics should be allowed to have a subject matter regardless of whether that subject matter concerns fundamental reality (see Bennett 20I6: 29-30). Metaphysics can be about what ultimately exists or about what most basically grounds what. But it need not be-metaphysicians also investigate the world we experience in ordinary, everyday life. Regardless of what we say about the bottom level of reality, metaphysical disputes about nonbasic reality, like what constitutes personal identity, are still worth having (see Barnes 20I4). This criterion is important when reading Nietzsche because it allows for Nietzsche to have a positive metaphysical project without believing that something like 'will to power' constitutes fundamental reality - a thorny issue subject to much debate. The success or failure of the metaphysical reading should not solely depend on whatever Nietzsche did or did not think about ultimate reality.

Before moving on, I want to address a potential worry. Are these criteria too broad? It looks like the criteria can be satisfied by all sorts of apparently nonmetaphysical endeavors, such as cultural studies, sociology, and political science. These fields appear to distinguish their studies from traditional scientific inquiry and defend claims about nonbasic reality. Are they therefore doing metaphysics? I think the answer is 'yes'. Many forms of inquiry involve metaphysical inquiry. Metaphysics concerns the nature of the world outside what the sciences tell us. In this way, metaphysical philosophy is often part and parcel of other areas of study. Metaphysics is not isolated to academic philosophy-metaphysical assumptions, claims, and theories are woven into and arise from other areas of thought, just like ethical, aesthetic, and epistemological assumptions, claims, and theories are part and parcel of other areas of study, from media studies to anthropology. Yet metaphysics remains distinguishable enough to retain the name-again, just like ethics, aesthetics, and epistemology. As a result, I am not swayed by the worry.

The criteria I have given lead to significant consequences concerning how we should understand Nietzsche's relation to metaphysics. Surprisingly few secondary readers define metaphysics before jumping into a discussion of Nietzsche and metaphysics. And, unfortunately, those who address the issue offer characterizations that fall short. For example, Clark and Dudrick assert that 'metaphysics is a body of (purported) metaphysical truths' (Clark and Dudrick 20I2: I 5, cf. Clark 2009). But this fails to satisfy the three criteria given above. 
First, it does not distinguish metaphysics from science. Second, it is consistent with making no commitments about the nature of reality, given that the truthmaker of '(purported) metaphysical truths' need not be the way the world is. And third, the characterization is compatible with the view that metaphysics exclusively investigates fundamental reality and ignores the world of everyday experience.

Other characterizations are also worrisome. Welshon writes that 'metaphysics studies the basic elements of existence' (Welshon 2004: 75). But there can be worthwhile metaphysical inquiry into the nonbasic elements of existence. This criticism also applies to Poellner's view that 'knowledge . . . of a metaphysical kind' is 'knowledge about that which exists in itself in some ultimate sense' (Poellner 1995: 29). Metaphysics need not be about what ultimately exists. Finally, I have claimed that metaphysical philosophy addresses 'the way the world is' (Remhof 20I7: 2) and makes 'general claims about the nature of reality' (Remhof 20I8: 3). Yet, science does this too, and so again more is needed.

Here is one thing we should not do when attempting to understand Nietzsche's relation to metaphysics. We should not identify metaphysics in general with the two-world metaphysical views he attacks, despite the fact that Nietzsche himself often does this. I see no good reason to think that we should be required to embrace Nietzsche's specialized language concerning what metaphysics is when talking about metaphysics in general, despite the fact that his attacks on certain metaphysical positions successfully pick out views held in the history of philosophy from Plato to Kant. Nietzsche's term 'metaphysics' does not capture what metaphysics is simpliciter. We can jettison two-world metaphysics and still do metaphysics.

Failure to notice the distinction between metaphysics in general and two-world metaphysics has long obfuscated interpretations of Nietzsche, whether one supports the metaphysical reading or the non-metaphysical reading. For example, Haar writes that 'any thought or belief that separates, opposes, or sets a hierarchy between a "world of appearances" and a "true world" is a metaphysics' (Haar I996: x). Cox holds that "metaphysics refers to discourse about what is above, beyond, or outside physis or nature' (Cox 1999: 6, see also 7I-72). And Ansell-Pearson repeatedly discusses Nietzsche's challenge to 'religion and metaphysics' in HH, as if the two stand and fall together (Ansell-Pearson 2018: 20 , see also 30,68, I 50 ). It is true that Nietzsche attacks otherworldly conceptions of metaphysics. This is why he calls himself a 'godless anti-metaphysician' (GS 344). But metaphysical philosophy need not divide worlds or be religious in any way. Thinking otherwise obscures the task of gaining a clear understanding of what positive metaphysical commitments Nietzsche might possibly have.

\section{Nietzsche on What Metaphysics Is}

Now back to the issue at hand: do Nietzsche's own responses to the metaphysical question concerning opposites satisfy the three criteria that characterize metaphysics, such that we can say he believes that there are metaphysical answers to the question that do not rely on dividing worlds? For this task we return to the 
first passage of $\mathrm{HH}$, which addresses the issue nicely. Looking at Nietzsche's view of metaphysics in $\mathrm{HH}$ is also quite telling, first, because it is often believed that Nietzsche is at his most antimetaphysical in $\mathrm{HH}$ - that $\mathrm{HH}$ is meant to stamp out the metaphysical picture of The Birth of Tragedy-and, second, because it is commonly thought that Nietzsche becomes more sympathetic to metaphysical philosophy in his later works, like BGE, GM, and TI (see, e.g., Clark 2009). Thus, if it can be shown that Nietzsche has a positive attitude toward metaphysics in $\mathrm{HH}$, we should expect that it can be shown elsewhere.

Here is more of the first passage of $\mathrm{HH}$ :

Historical philosophy, on the other hand, which can no longer be separated from natural science, the youngest of all philosophical methods, has discovered in individual cases (and this will probably be the result in every case) that there are no opposites . . . according to this explanation there exists, strictly speaking, neither an unegoistic action nor completely disinterested contemplation; both are only sublimations, in which the basic element seems almost to have dispersed and reveals itself only under the most painstaking observation. (HH I: I)

First notice that these claims concern the nature of reality, such as, for example, the nature of human action. Nietzsche explicitly includes an existential quantifier: 'there exists, strictly speaking, neither an unegoistic action nor completely disinterested contemplation'. Recall also that the passage begins by addressing the existence of other features of reality, including sentience and desire. Thus, the passage satisfies the second criterion for offering a metaphysics. Nietzsche is talking about the way the world is. Moreover, since features of the world like action, sentience, desire, and egoism are not phenomena that we take to make up fundamental reality, the passage also satisfies the third criterion. Nietzsche is talking about the nature of reality that we encounter in everyday experience.

Does the passage distinguish metaphysics from science? At first glance, it might not seem so. Nietzsche says that 'philosophy . . . can no longer be separated from natural science'. But he does not mean that these disciplines are simply one and the same. His point is that philosophical inquiry should not be isolated from scientific inquiry. Indeed, he believes philosophical inquiry can make progress if modeled on scientific inquiry.

How might this work? HH I: I provides an example. The passage is titled 'Chemistry of concepts and sensations'. How can chemistry illuminate the nature of opposites? Nietzsche says there exists 'neither an egoistic action nor completely disinterested contemplation; both are only sublimations'. In chemistry, sublimation is a process where a solid state moves to a gaseous state without passing through the intermediary liquid state. Nietzsche suggests that we should apply this concept to understanding the nature of opposites: we think opposites exist because we ignore the hidden middle process between complex phenomena. The middle process, which ties apparent opposites together, 'reveals itself only under the most painstaking observation'. Chemistry might then supply a way of 
understanding why there are no opposites in areas of philosophical concern. In this passage, then, Nietzsche distinguishes between metaphysics and science. The metaphysical subject matter Nietzsche is concerned with includes the existence and nature of phenomena such as action, sentience, desire, and egoism, and he suggests that we investigate this subject matter using a certain branch of scientific inquiry as a model.

Nietzsche's preferred response to the metaphysical question concerning opposites in $\mathrm{HH}$ therefore satisfies the three criteria that characterize metaphysical philosophy. And his response does not require dividing worlds. As a result, we see that Nietzsche believes there are metaphysical answers to the question of opposites that do not rely on two-world metaphysics. The answer that Nietzsche thinks many metaphysicians give to the question of opposites, from Plato to Kant, does not imply that he discards metaphysics as distinctively problematic. Metaphysical philosophy need not divide worlds.

There is an implication here worth addressing. We often see Nietzsche objecting to the need people have for embracing certain philosophical views, rather than the content of such views. With respect to religion, for example, while he obviously rejects the content of Christianity, he is more focused on exposing and attacking what motivates people to accept such a view. It is then possible that what Nietzsche finds problematic about metaphysics is that metaphysical philosophy answers to a need that Nietzsche regards as problematic.

What need? In general, the need for something permanent or unchanging, like the thing in itself, the Forms, or the Kingdom of Heaven, which might grant us free will and morality, or objective, mind-independent truths, or eternal salvation, all of which might ease the frustration that results from enduring this ever-changing world (see, e.g., KSA I 2:8[2]; TI 'Reason' I, 5, 6; 'World'; EH 'Books' BT 3; GS 347; HH I: 5, I6). This need is therefore satisfied by embracing two-world metaphysics. And, as we know, for Nietzsche embracing two-world views deprives reality of its 'value', 'meaning', and 'truthfulness' (EH P: 2).

However, if Nietzsche thinks metaphysical philosophy is possible without having to divide worlds, as I have just argued, then there is no reason to think that the 'metaphysical need' (HH I: 37, see also EH 'Books' HH 6) to endorse two-world views renders metaphysics in general problematic. Put differently, it is not the case that Nietzsche thinks all metaphysical philosophy must be derived from the problematic psychological need that he ousts. Metaphysics can get underway independently of the desire to endorse two-world metaphysical views (for a nice discussion about how Nietzsche thinks ressentiment leads people to embrace two-world metaphysical positions, see Jenkins 2019).

In sum, I have suggested that neither a primary question that metaphysics asks, nor a primary answer that metaphysics gives, renders metaphysics specially problematic. This is a significant blow to the non-metaphysical reading. But the reading is not dead in the water. There are two other ways that metaphysics might be distinctively problematic: metaphysical methodology might be problematic, or the subject matter of metaphysics, once we jettison two-world metaphysics, might be problematic. I now address each in turn. 


\section{Continuity of Method}

Does Nietzsche think that metaphysical methodology is particularly worrisome? I have already suggested that doing metaphysical philosophy by dividing things into a 'true world' and an 'apparent world' does not imply that metaphysics, in general, has a special problem. What other ways does Nietzsche think we do metaphysics?

Consider an example from Nietzsche's texts:

What? And others even say that the external world is the work of our organs? But then our body, as a part of this external world, would be the work of our organs! But then our organs themselves would bethe world of our organs! It seems to me that this is a complete reductio ad absurdum, assuming that the concept of a causa sui is something fundamentally absurd. (BGE I $_{5}$ )

This certainly looks like metaphysical reasoning. The conclusion seems to be that, against certain versions of idealism, the external world is not a product of our sensory organs. How does Nietzsche arrive at this conclusion? He examines entailment relations. He looks at the logical consequences of a particular view. And he exposes a contradiction given a plausible starting assumption. None of these methods are distinctive to metaphysics.

There are, of course, other ways Nietzsche seems to do metaphysics. But, again, none are limited to metaphysical thinking. In what follows, let 'NMC' stand for a non-metaphysical context and 'MC' stand for a metaphysical context. Nietzsche offers imaginative thought experiments (for NMC see GS 34I; GM II: 24; for MC see TL; GS 354, I I I; HH I: I 8), debunking arguments (for NMC see GS I Io; D 95; for MC see GS I2I, 57), origin of belief arguments (for NMC see HH I: I 2 , I45; GS 335, 353, 355; GM I; BGE 20, 260; for MC see HH I: 5, IO, I9; GS III; GM I: I3; BGE 2; TI 'Reason' I, 5; 'Errors' 3), and inferences to the best explanation (for NMC see GM II: 19-23; for MC see BGE 36; GS 344, 354). He appeals to what can be empirically confirmed (for NMC see BGE I34; GM I: 2, 4; for MC see HH I: I6; TI 'Reason' 3). And he commonly assumes and endorses the legitimacy of theoretical virtues, like scope, simplicity, and pragmatic applicability (see Remhof 20I 8: 69 n. 25). These methodological tools are in play throughout his corpus, in both metaphysical and non-metaphysical contexts.

I suspect that readers will point out that I have overlooked something crucial: metaphysics, unlike many other ways of doing philosophy, typically proceeds by a priori means. And, since it is common to think that Nietzsche rejects such means, it could be argued that Nietzsche does indeed think that metaphysics is problematic.

However, this challenge cannot be sustained. As I mentioned above, Nietzsche appears sympathetic to the naturalist view that philosophy should be, in some sense, continuous with the sciences. Importantly, Nietzsche primarily champions science for its method, rather than for its particular results. For instance, he writes that 'the scientific spirit rests upon an insight into methods, and if those methods were lost, then all the results of science could not prevent a restoration of 
superstition and nonsense' (HH I: 635, my translation, see also A 59). Science, of course, typically operates by a posteriori means, that is, by observation of the world. Thus, even if the use of a priori reasoning is distinctive to metaphysics, this would not show that Nietzsche thinks metaphysics has a special problem. If Nietzsche were indeed a metaphysician, his metaphysical methodology would be at least continuous with scientific methodology. The worry that a priori reasoning renders metaphysics distinctively problematic then falls away.

One more point concerning methodology requires attention. When Nietzsche discusses metaphysical philosophy he often focuses on philosophical systems erected by thinkers like Plato, Kant, Hegel, and Schopenhauer. Building such systems is a particular way of doing metaphysics-and one Nietzsche seems to reject. He declares, 'I mistrust all systematists and avoid them. The will to system is a lack of integrity' (TI 'Maxims' 26). So perhaps Nietzsche thinks the desire to construct metaphysical systems is a strategy that renders metaphysics specially problematic.

How might we respond? Notice that the metaphysical systems Nietzsche seems to reject are often those that attempt to derive philosophical conclusions using a priori reasoning, or those that depend on some self-evident, a priori truths. If so, this objection dissolves under my remarks above on the a priori. System or no system, Nietzsche can still do metaphysics naturalistically.

But maybe the mere attempt to offer a systematic metaphysics, no matter how the system gets built, is what Nietzsche finds troublesome. And here I am just not convinced. One reason is that metaphysics is possible without the kind of systematization found in Kant, Hegel, Schopenhauer, and others. In contemporary philosophy, for example, some metaphysicians are particularists. Particularists examine metaphysical issues and draw metaphysical conclusions about concrete, particular cases, and in doing so they do not expect there to be any general principles systematizing our judgments (see Korman 2010; Hirsch 2002: I I3-I4; Comesaña 2008: 34). Particularists can accept general principles, of course, but in cases of conflict they suggest that our judgments about concrete cases should win out. It certainly looks like Nietzsche is sympathetic to particularism. After all, this way of approaching philosophical issues lies at the heart of his aphoristic methodology. Aphorisms often explore the nature of particular phenomena from particular perspectives.

At the same time, some of what seem to be Nietzsche's metaphysical commitments appear systematic. Appeal to the existence and nature of drives and affects to explain human psychology and action, for instance, might be a good candidate. Another might be his rejection of substance, ego, and the like, which Nietzsche undermines by appeal to what can be confirmed in experience. In the end, then, Nietzsche's apparent rejection of philosophical system-building does not show that he thinks metaphysics across the board is distinctively problematic.

\section{Continuity of Subject Matter}

We now come to the final issue. Does Nietzsche think the subject matter of metaphysics is specially problematic? On my account, the answer is 'no'. To see 
why, we can again utilize a strategy introduced by Bennett (20I6: 34ff.). If metaphysical philosophy is intertwined with non-metaphysical philosophy in someone's writings, then the subject matter of metaphysics must be treated as continuous with the subject matter of non-metaphysical philosophy. I claim this is the case in Nietzsche's texts.

Here are some examples. In Twilight of the Idols, Nietzsche asserts that 'there are no moral facts at all. Moral judgment has this in common with religious judgment, that it believes in realities which do not exist' (TI 'Improvers' I, see also D IO3). It cannot be unproblematic to deny the existence of moral facts, however, but problematic to talk about what facts are, or what moral facts are, and what they are like if there are any. These issues involve metaphysics.

In Antichrist, Nietzsche writes that 'In Christianity neither morality nor religion has even a single point of contact with reality. Nothing but imaginary causes ("God", "soul", "ego", "spirit", "free will"-for that matter, "unfree will”), nothing but imaginary effects ("sin", “redemption”, "grace”, "punishment", "forgiveness of sins")' (A I5). But it cannot be unproblematic to claim that Christianity is not grounded in reality, or that Christianity operates by way of imaginary causes and effects, yet problematic to talk about the nature of reality or the nature of cause and effect. If it is not a problem to say that Christianity does not have 'a single point of contact with reality', then it is not a problem to talk about the way the world is. There is no need to remain agnostic, for instance, or maintain a principled silence about the nature of reality.

Examples like these are easy to find in Nietzsche's texts. In Beyond Good and Evil, Nietzsche holds that 'the way is open for new versions and refinements of the soul-hypothesis', such as "'mortal-soul", and "soul as subjective multiplicity", and "soul as social structure of the drives and affects", (BGE I2). If we can talk about these new versions of the 'soul', though, we can certainly talk about what a person is. In The Gay Science, Nietzsche writes that 'My idea is clearly that consciousness actually belongs not to man's existence as an individual but rather to the community- and herd-aspects of his nature' (GS 354). If discussing the origin of consciousness is acceptable, then discussing the features of consciousness is acceptable. And it certainly cannot be unproblematic to discuss a revaluation of all values or examine the value of moral values or claim that philosophers should create new values, as Nietzsche famously does, but somehow deeply worrisome to talk about what a value is, what bringing values into existence consists in, and so forth. The list could go on.

The philosophical issues Nietzsche investigates are intertwined with metaphysical issues. They cannot sensibly be pulled apart. Any attempt to do so would result in a failure to understand what Nietzsche is doing as a philosopher. For Nietzsche the subject matter of metaphysics is not specially problematic.

\section{Summary and Conclusion}

The non-metaphysical reading holds that Nietzsche does not have a positive, systematic metaphysical project. On this account, Nietzsche thinks metaphysical philosophy is somehow distinctively problematic in relation to other areas of 
philosophy. Against this approach, I have suggested that Nietzsche does not believe that metaphysics has any problematic feature that is reasonably widespread within the discipline, but nonexistent or at least notably less widespread outside the discipline.

We have seen that one of the primary philosophical questions Nietzsche believes metaphysics asks-how could something arise from its opposite?-does not constitute a special problem. The primary way that Nietzsche thinks metaphysical philosophy answers that question, namely, by dividing things into 'true' and 'apparent' worlds, does not constitute a special problem. The philosophical methodology of metaphysical inquiry does not constitute a special problem. And the subject matter of metaphysical philosophy does not constitute a special problem. This presents a significant challenge to the non-metaphysical reading.

It is not clear how commentators who support the non-metaphysical reading can respond. One way would be to say that Nietzsche thinks metaphysics is problematic for some reason I did not address. But I do not see any way that can avoid all the arguments given above. Another way would be to challenge the three criteria of metaphysics that I provided. I have not developed any substantive arguments to support them. Yet they should all seem prima facie plausible: metaphysical philosophy should distinguish itself from science, make claims about the nature of reality, and not be required to make claims about fundamental reality.

The non-metaphysical reading could argue that Nietzsche's philosophy fails to satisfy one of the criteria. Perhaps Nietzsche believes we should replace metaphysics with science, for instance, or maybe he denies that we can make claims about reality. But Nietzsche never pursues such a radical replacement, and not only does he make statements about the nature of reality all over the place, we have seen that such claims are woven into his philosophical project as a whole. Thus, I think the reading I have presented should cause significant concern for those who want to embrace the non-metaphysical reading.

At the same time, however, I have not laid out any of Nietzsche's positive, systematic metaphysical commitments. I have only argued that because Nietzsche does not think metaphysics is distinctively problematic, we have strong reason to prefer the metaphysical reading. This reading should be preferred because it can get off the ground-it is not undermined from the outset, unlike the alternative. The exact features of Nietzsche's positive, systematic metaphysical project are up for debate-and I suspect they always will be-but first things first: we need to be approaching Nietzsche as a metaphysician.

JUSTIN REMHOF

OLD DOMINION UNIVERSITY jrembof@odu.edu

\section{References}

Ansell-Pearson, Keith. (2018) Nietzsche's Search for Philosophy: On the Middle Writings. London: Bloomsbury.

Aristotle. (2016) Metaphysics. Translated by C. D. C. Reeve. Indianapolis: Hackett Publishing. 
Barnes, Elizabeth. (20I4) 'Going Beyond the Fundamental: Feminism in Contemporary Metaphysics'. Proceedings of the Aristotelian Society, I I4, 335-35 I.

Bennett, Karen. (20I6) 'There is No Special Problem with Metaphysics'. Philosophical Studies, I73, $2 \mathrm{I}-37$.

Berry, Jessica. (2005) 'Perspectivism as "Ephexis" in Interpretation'. Philosophical Topics, 33: 2, I9-44. Berry, Jessica. (20I I) Nietzsche and the Ancient Skeptical Tradition. Oxford: Oxford University Press.

Clark, Maudemarie. (2009) 'Anti-metaphysics I: Nietzsche'. In Robin Le Poidevin, Peter Simmons, Andrew McGonigal, and Ross P. Cameron (eds.), The Routledge Companion to Metaphysics (London: Routledge), I6I-70.

Clark, Maudemarie, and David Dudrick. (20I2) The Soul of Nietzsche's Beyond Good and Evil. Cambridge: Cambridge University Press.

Comesaña, Juan. (2008) 'Could There Be Exactly Two Things?'. Synthese, I62, 3 I-35.

Cox, Christoph. (1999) Nietzsche: Naturalism and Interpretation. Berkeley: University of California Press.

Crisp, Thomas. (2016) 'On Naturalistic Metaphysics'. In Kelly James Clark (ed.), Blackwell Companion to Naturalism (Malden, MA: Wiley-Blackwell), 6I-74.

Derrida, Jacques. (1978) Writing and Difference. Translated by Alan Bass. Chicago: The University of Chicago Press.

Doyle, Tsarnia. (2018) Nietzsche's Metaphysics of the Will to Power: The Possibility of Value. Cambridge: Cambridge University Press.

Emden, Christian. (2014) Nietzsche's Naturalism: Philosophy and Life Sciences in the Nineteenth Century. Cambridge: Cambridge University Press.

Haar, Michael. (1996) Nietzsche and Metaphysics. Translated and edited by Michael Gendre. Albany: State University of New York Press.

Hales, Steven D., and Rex Welshon. (2000) Nietzsche's Perspectivism. Urbana: University of Illinois Press.

Heidegger, Martin. (1987) Nietzsche Vol. III: The Will to Power as Knowledge and as Metaphysics. Translated by David Krell. San Francisco: Harper and Row Publishers.

Himmelmann, Beatrix. (2019) 'Metaphilosophy and Metapolitics in Nietzsche and Heidegger'. In Paul S. Loeb and Matthew Meyer (eds.), Nietzsche's Metaphilosophy: The Nature, Method, and Aims of Philosophy (Cambridge: Cambridge University Press), 207-26.

Hirsch, Eli. (2002) 'Against Revisionary Ontology'. Philosophical Topics, 30, 103-27.

Houlgate, Steven. (1986) Hegel, Nietzsche, and the Criticism of Metaphysics. Cambridge: Cambridge University Press.

Jenkins, Scott. (2019) 'Nietzsche's Psychology of Metaphysics (Or, Metaphysics as Revenge)'. In Paul S. Loeb and Matthew Meyer (eds.), Nietzsche's Metaphilosophy: The Nature, Method, and Aims of Philosophy (Cambridge: Cambridge University Press), 227-46.

Kaufmann, Walter. (1974) Nietzsche: Philosopher, Psychologist, Antichrist. Princeton: Princeton University Press.

Kim, Jaegwon, and Ernest Sosa, eds. (1999) Metaphysics: An Anthology. I ${ }^{\text {st }}$ ed. Malden, MA: Wiley-Blackwell.

Korman, Daniel Z. (2010) 'Strange Kinds, Familiar Kinds, and the Charge of Arbitrariness'. Oxford Studies in Metaphysics, 5, I99-44.

Ladyman, James, and Don Ross. (2007) Every Thing Must Go: Metaphysical Naturalized. Oxford: Oxford University Press.

Le Poidevine, Robin. (2009) 'General Introduction: What is Metaphysics?'. In Robin Le Poidevine, Peter Simons, Andrew McGonigal, and Ross P. Cameron (eds.), The Routledge Companion to Metaphysics (London: Routledge), xviii-xxii.

Loux, Michael, and Thomas Crisp. (2017) Metaphysics: A Contemporary Introduction. $4^{\text {th }}$ ed. New York: Routledge.

Manley, David. (2009) 'Introduction: A Guided Tour of Metametaphysics'. In David J. Chalmers, David Manley, and Ryan Wasserman (eds.), Metametaphysics: New Essays on the Foundations of Ontology (Oxford: Oxford University Press), I-37. 
Pippin, Robert. (2010) Nietzsche, Psychology, and First Philosophy. Chicago: University of Chicago Press.

Poellner, Peter. (1995) Nietzsche and Metaphysics. Oxford: Oxford University Press.

Poellner, Peter. (2009) 'Nietzschean Freedom'. In Ken Gemes and Simon May (eds.), Nietzsche on Freedom and Autonomy (Oxford: Oxford University Press), I 5 I-80.

Poellner, Peter. (2013) 'Nietzsche's Metaphysical Sketches: Causality and the Will to Power'. In Ken Gemes and John Richardson (eds.), The Oxford Handbook to Nietzsche (Oxford: Oxford University Press), 675-700.

Remhof, Justin. (20I 8) Nietzsche's Constructivism: A Metaphysics of Material Objects. New York: Routledge.

Richardson, John. (1996) Nietzsche's System. New York: Oxford University Press.

Schacht, Richard. (1983) Nietzsche. London: Routledge and Kegan Paul.

Schaffer, Jonathan. (2009) 'On What Grounds What'. In David Chalmers, David Manley, and Ryan Wasserman (eds.), Metametaphysics: New Essays on the Foundations of Ontology (Oxford: Oxford University Press), 347-83.

Sider, Theodore. (2008) 'Introduction'. In Theodore Sider, John Hawthorne, and David Zimmerman (eds.), Contemporary Debates in Metaphysics (Oxford: Blackwell), I-7.

Sider, Theodore. (20II) Writing the Book of the World. Oxford: Oxford University Press.

Stern, Tom. (2019) 'Nietzsche's Ethics of Affirmation'. In Tom Stern (ed.), The New Cambridge Companion to Nietzsche (Cambridge: Cambridge University Press), $35 \mathrm{I}-73$.

van Inwagen, Peter. (1998) 'The Nature of Metaphysics'. In Steven Laurence and Cynthia MacDonald (eds.), Contemporary Readings in the Foundations of Metaphysics (Oxford: Blackwell), I I-2I.

van Inwagen, Peter. (2007) 'Metaphysics'. In Edward N. Zalta (ed.), The Stanford Encyclopedia of Philosophy (Winter 2013 ed.)

Welshon, Rex. (2004) The Philosophy of Nietzsche. Montreal: McGill-Queen's University Press. 